\title{
PENERAPAN MODEL KOOPERATIF WORDSQUARE UNTUK MENINGKATAN PRESTASI BELAJAR SISWA PADA PEMBELAJARAN KIMIA POKOK BAHASAN KOLOID DI KELAS XI SMKN 2 PEKANBARU
}

\author{
Lidiana Fitri ${ }^{1}$, Nofianti ${ }^{1}$, Susilawati ${ }^{2}$ \\ ${ }^{1}$ SMKN 2 Pekanbaru, ${ }^{2}$ Prodi Pendidikan Kimia FKIP UR Pekanbaru \\ Email : ardinafitri@yahoo.co.id
}

\begin{abstract}
Abstrak
Penelitian penerapan model pembelajaran kooperatif word square telah dilakukan untuk meningkatkan prestasi belajar kimia siswa pada pokok bahasan Koloid di kelas XI SMKN 2 Pekanbaru. Bentuk penelitian yang dilakukan adalah penelitian eksperimen dengan desain pretest-posttest. Sampel terdiri dari dua kelas yaitu kelas XI Kimia 1 sebagai kelas eksperimen dan kelas XI Kimia 2 sebagai kelas kontrol yang dipilih secara acak setelah dilakukan uji homogenitas. Kelas eksperimen merupakan kelas yang diberi perlakuan dengan menerapkan model pembelajaran kooperatif tipe Word square. Teknik analisa data yang digunakan adalah uji-t. Berdasarkan hasil penelitian pengolahan data akhir menggunakan rumus uji-t diperoleh t-hitung $>\mathrm{t}$-tabel yaitu 3,49 $>1,67$ artinya hipotesis penerapan model pembelajaran kooperatif tipe word square dapat meningkatkan prestasi belajar siswa pada pokok bahasan Koloid dikelas XI SMKN 2 Pekanbaru diterima dengan persentase peningkatan sebesar 13,71\%.
\end{abstract}

Kata Kunci: Pembelajaran Kooperatif, Word square, Koloid dan Prestasi Belajar.

\begin{abstract}
The research about application of word Square cooperative learning model has been done to improve student's achievement in colloid matter at $11^{\text {th }}$ SMKN 2 Pekanbaru. The purpose of this research was to know if the application of Word Square cooperative learning model could increase student achievement in colloid matter. Subject of this research were students at XI Kimia 1 class and XI Kimia 2 class in academic year 2011/2012. XI Kimia 1 class was randomly selected as experiment class and XI Kimia 2 class as control class. Research results revealed that application cooperative learning Word Square model was capable to improve student's achievement in colloid matter. This research pretest-posttest design by using $t$-test ( $\mathrm{t}$ arithmetic $>\mathrm{t}$ table; $3.49>1.67)$. The application this model capable to increase students achievement in colloid matter about $13.71 \%$.
\end{abstract}

Keywords: cooperative learning, Word Square, colloid and learning achievement 


\section{PENDAHULUAN}

Pelajaran kimia merupakan salah satu ilmu yang menuntut siswa memahami konsep-konsep yang terkandung di dalamnya. Konsep-konsep tersebut menuntut siswa untuk belajar dan beraktivitas semaksimal mungkin baik secara mandiri ataupun bimbingan guru, dan aktif dalam pemecahan masalah yang ditemui dalam belajar. Materi koloid merupakan materi yang bersifat teori dan guru cenderung menyampaikannya dengan metode ceramah. Akibatnya siswa menjadi pasif menerima materi dari guru karena kurang melibatkan aktifitas siswa secara maksimal. Hal ini menyebabkan materi pelajaran tidak dapat dipahami siswa secara utuh sehingga berdampak pada prestasi belajar siswa. Menurut Thomas dalam Hamid (2011) menyatakan bahwa setelah 10 menit belajar, siswa cenderung akan kehilangan konsentrasi untuk mendengarkan pelajaran yang diberikan oleh pengajar. Hal ini tentu saja akan membuat siswa kurang perhatian terhadap pelajaran. Nilai rata-rata yang diperoleh siswa SMKN 2 Pekanbaru pada pokok bahasan koloid pada tahun ajaran 2010/2011 yaitu 70. Nilai rata-rata ini masih dibawah Kriteria Ketuntasan Minimum (KKM) yang ditetapkan oleh sekolah yaitu 75 .

Permasalahan tersebut dapat diatasi dengan penerapan pembelajaran yang memungkinkan siswa aktif belajar, mengurangi kebosanan dan menumbuhkan minat belajar. Suatu pembelajaran aktif akan cenderung membuat siswa lebih mengingat (retention rate of knowledge) mata pelajaran yang diberikan (Hamid, 2011). Salah satu model pembelajaran yang dapat mengaktifkan siswa adalah model pembelajaran kooperatif.

Model pembelajaran kooperatif word square merupakan model pembelajaran yang mana siswa belajar dalam kelompok dan adanya uji pemahaman materi yang dilakukan dengan permainan. Model pembelajaran kooperatif word square dapat menciptakan suasana belajar yang menyenangkan dan membuat pelajaran lebih mudah dipahami dan lebih lama diingat. Model Pembelajaran word square merupakan model pembelajaran yang memadukan kemampuan menjawab pertanyaan dengan kejelian dalam mencocokkan jawaban pada kotak-kotak jawaban. Mirip seperti mengisi TekaTeki Silang tetapi bedanya jawabannya sudah ada namun disamarkan dengan menambahkan kotak tambahan dengan sembarang huruf/angka penyamar atau pengecoh. Model pembelajaran ini sesuai untuk semua mata pelajaran.Tinggal 
bagaimana Guru dapat memprogram sejumlah pertanyaan terpilih yang dapat merangsang siswa untuk berpikir efektif. Tujuan huruf/angka pengecoh bukan untuk mempersulit siswa namun untuk melatih sikap teliti dan kritis (Santoso, 2011).

Menurut Suyatno (2009), tahapan pembelajaran Word square adalah sebagai berikut :

a. Sampaikan materi sesuai kompetensi.

b. Bagikan lembaran kegiatan word square.

c. Siswa disuruh menjawab soal kemudian mengarsir huruf dalam kotak sesuai jawaban.

d. Berikan poin setiap jawaban benar dalam kotak word square (jawaban benar $=1$ poin dan jawaban salah $=0$ poin)

Penelitian tentang penerapan model pembelajaran word square telah dilakukan oleh Wijana, E, (2011), untuk meningkatkan hasil belajar siswa pada pembelajaran matematika (penelitian tindakan kelas siswa VIIIC SMP Al-Falah Karawangi Depok), Hasilnya terjadi peningkatan persentase siswa yang belajar tuntas pada siklus 2 menjadi $86,67 \%$.

\section{METODE PENELITIAN}

Bentuk penelitian merupakan penelitian eksperimen dengan desain pretestposttest yang dilaksanakan di kelas XI SMK Negeri 2 Pekanbaru semester genap T.P 2011/2012. Populasi penelitian adalah seluruh siswa kelas XI yang terdiri dari 6 kelas. Sampel dalam penelitian dipilih dua kelas yang homogen dengan cara melakukan uji normalitas dan uji homogenitas dengan soal pretest maka didapatkan kelas XI Kimia 1 dan XI Kimia 2 sebagai sampel. Hipotesis dalam penelitian ini adalah penerapan model pembelajaran kooperatif word square dapat meningkatkan prestasi belajar siswa pada pokok bahasan koloid di kelas XI SMK Negeri 2 Pekanbaru.

Penelitian menggunakan rancangan randomized control group pretest-posttest. Sebelum diberi perlakuan, kedua kelas diberikan pretest kemudian diberi perlakuan dengan menerapkan model pembelajaran kooperatif word square pada kelas eksperimen sedangkan kelas kontrol tidak menggunakan model pembelajaran kooperatif word square. Setelah proses pembelajaran, kedua kelas diberikan posttest (Nazir, 2003).

Langkah - langkah teknik analisis data dalam penelitian adalah : 
1. Prasyarat Analisis

a. Uji Normalitas

Uji statistik yang digunakan adalah uji t. Pengujian statistik dengan menggunakan uji t dapat dilakukan berdasarkan kriteria bahwa data yang diolah berdistribusi normal. Oleh sebab itu sebelum dilakukan pengolahan data, terlebih dahulu dilakukan uji normalitas terhadap data yang akan diolah. Pengujian normalitas menggunakan rumus:

$$
\chi^{2} \text { hitung }=\sum_{i=1}^{k} \frac{\left(O_{i}-E_{i}\right)^{2}}{E_{i}}
$$

Kriteria pengujiannya adalah jika $\chi^{2}$ hitung $<\chi^{2}$ tabel maka dapat dikatakan sampel berdistribusi normal. Nilai $\chi_{\text {tabel }}^{2}$ diperoleh dari table distribusi $\chi_{\text {tabel }}^{2}$ diperoleh dari tabel distribusi $\chi^{2}$ dengan peluang $\alpha(\alpha=0,05)$ dan $\mathrm{dk}=(\mathrm{k}-3)$.

b. Uji Homogenitas

Data yang digunakan untuk uji homogenitas adalah hasil pretest yang diuji dengan menggunakan uji-t. Untuk menentukan rumus thitung yang akan digunakan dalam pengujian hipotesis, maka perlu diuji dahulu varians kedua sampel homogen atau tidak. Pengujian homogenitas varians menggunakan uji F dengan rumus:

$$
F_{\text {hit }}=\frac{\text { varians terbesar }}{\text { varians terkecil }}
$$

Sedangkan untuk menghitung varians dari masing-masing kelompok digunakan rumus:

$$
S_{1}{ }^{2}=\frac{n_{1} \sum x_{1}{ }^{2}-\left(\sum x_{1}\right)^{2}}{n_{1}\left(n_{1-1}\right)} \quad \text { dan } \quad S_{2}{ }^{2}=\frac{n_{2} \sum x_{2}{ }^{2}-\left(\sum x_{2}\right)^{2}}{n_{2}\left(n_{2-1}\right)}
$$

Jika pada perhitungan data awal diperoleh $F_{\text {hitung }}<F_{\text {tabel, }}$, maka sampel dikatakan mempunyai varians yang sama atau homogen. Kemudian dilanjutkan dengan menguji kesamaan rata-rata (uji dua pihak) menggunakan rumus t-hitung sebagai berikut:

$$
t=\frac{\overline{X_{1}}-\overline{X_{2}}}{S \sqrt{\frac{1}{n_{1}}+\frac{1}{n_{2}}}}
$$

dengan S gabungan:

$$
S^{2}=\frac{\left(n_{1}-1\right) S_{1}{ }^{2}+\left(n_{2}-1\right) S_{2}{ }^{2}}{n_{1}+n_{2}-2}
$$

Dengan kriteria pengujian thitung terletak antara $-t_{\text {tabel }}$ dan $t_{\text {tabel }}\left(-t_{\text {tabel }}<t_{\text {thitung }}<t_{\text {tabel }}\right)$, dimana tabel didapat dari daftar distribusi t dengan $\mathrm{dk}=\mathrm{n}_{1}+\mathrm{n}_{2}-2$ dengan peluang $1-1 / 2$ $\alpha$ dimana $\alpha=0,05$ maka sampel dikatakan homogen. 


\section{Uji Hipotesis}

Rumus uji-t di atas juga digunakan untuk perbandingan antara nilai kelas eksperimen dan kelas kontrol. Uji-t yang digunakan adalah uji-t pihak kanan dengan kriteria probabilitas (1- $\alpha$ ) untuk menguji hipotesis, dengan rumus sebagai berikut :

$$
\mathrm{t}=\frac{\bar{x}_{1}-\bar{x}_{2}}{S_{g} \sqrt{\frac{1}{n_{1}}+\frac{1}{n_{2}}}} \quad \quad \text { dengan } \quad S_{g}{ }^{2}=\frac{\left(n_{1}-1\right) S_{1}{ }^{2}+\left(n_{1}-1\right) S_{2}{ }^{2}}{n_{1}+n_{2}-2}
$$

Kriteria pengujian hipotesis $\left(\mathrm{H}_{1}\right)$ diterima jika thitung $>t_{\text {tabel }}$ dengan $\mathrm{dk}=\mathrm{n}_{1}+\mathrm{n}_{2}-2$ dengan $\alpha=0,05$. Untuk menentukan besar peningkatan prestasi belajar siswa, dilakukan dengan menggunakan koefisien determinasi $\left(\mathrm{r}^{2}\right)$ yang diperoleh dari rumus :

$$
t=\frac{r \sqrt{n-2}}{\sqrt{1-r^{2}}} \text { sehingga rumus menjadi } \quad r^{2}=\frac{t^{2}}{t^{2}+n-2}
$$

Sedangkan untuk menentukan presentase peningkatan (koefisien pengaruh) dari perlakuan digunakan rumus :

$$
\mathrm{Kp}=\mathrm{r}^{2} \times 100 \%
$$

(Subana dkk, 2000)

\section{HASIL DAN PEMBAHASAN}

Pengolahan data hasil penelitian dilakukan dengan teknik analisa data menggunakan metode statistik, meliputi prasyarat analisis dengan uji normalitas. Data pretest yang berdistribusi normal diuji kehomogenannya. Data yang telah diuji variansnya selanjutnya diuji kesamaan rata - rata dua pihak untuk mengetahui kehomogenan dua kelas. Berdasarkan hasil uji normalitas data materi pretest maka diperoleh data yang tercantum pada Tabel 2.

Tabel 2. hasil uji normalitas pretes.

\begin{tabular}{llllllll}
\hline Kelas & $\mathrm{F}$ & $\mu$ & $\mathrm{S}$ & $\mathrm{k}$ & $\mathrm{dk}=\mathrm{k}-3$ & $\chi^{2}$ hitung & $\chi^{2}$ tabel \\
\hline Eksp & 25 & 25,02 & 8,59 & 6 & 3 & 6,9797 & 7,81 \\
\hline Kontrol & 34 & 25,8 & 6,89 & 6 & 3 & 7,3515 & 7,81 \\
\hline
\end{tabular}

\section{Keterangan:}

$\mathrm{F}$ : jumlah data pada sampel

$\mu$ : nilai rata-rata sampel

$\mathrm{S}$ : simpangan baku

$\mathrm{k}$ : jumlah kelas pada tabel distribusi frekuensi

$\chi^{2}$ (chi): lambang statistik untuk menguji kenormalan 
Berdasarkan data pada Tabel 2 dapat dilihat bahwa sampel I diperoleh $\chi^{2}$ hitung $<\chi^{2}$ tabel yaitu $6,9797<7,81$ dan sampel II diperoleh $\chi^{2}{ }_{\text {hitung }}<\chi^{2}$ tabel yaitu $7,3515<7,81$. Hal ini menunjukkan bahwa kedua kelompok sampel berdistribusi normal.

Hasil uji normalitas postest maka diperoleh data yang tercantum pada Tabel 3.

Tabel 3. Hasil uji normalitas data postest

\begin{tabular}{llllllll}
\hline Kelas & $\mathrm{F}$ & $\mu$ & $\mathrm{S}$ & $\mathrm{k}$ & $\mathrm{dk}=\mathrm{k}-3$ & $\chi^{2}$ hitung & $\chi^{2}$ tabel \\
\hline Eksp & 25 & 87,26 & 7,69 & 6 & 3 & 6,94 & 7,81 \\
\hline Kontrol & 34 & 79,36 & 5,77 & 6 & 3 & 6,68 & 7,81
\end{tabular}

Keterangan:

F: jumlah data pada sampel

$\mu$ : nilai rata-rata sampel

$\mathrm{S}$ : simpangan baku

$\mathrm{k}$ : jumlah kelas pada tabel distribusi frekuensi

$\chi^{2}$ (chi): lambang statistik untuk menguji kenormalan

Berdasarkan data dari Tabel 3 dapat dilihat bahwa pada kelas eksperimen diperoleh $\chi^{2}$ hitung $<\chi^{2}$ tabel yaitu $6,94<7,81$ dan pada kelas kontrol 2 diperoleh $\chi^{2}$ hitung $<$ $\chi^{2}$ tabel yaitu $6,68<7,81$. Hal ini menunjukkan bahwa kedua kelompok sampel berdistribusi normal.

a. Uji homogenitas

Data yang digunakan untuk uji homogenitas dalam penelitian ini adalah data pretest materi Koloid. maka diperoleh data seperti tercantum pada Tabel 4.

Tabel 4. Hasil Uji Homogenitas

\begin{tabular}{lllcllll}
\hline Kelas & $\mathrm{N}$ & $\sum \mathrm{X}$ & $X$ & Ftabel & Fhitung & tabel & Thitung \\
\hline Eksp & 25 & 976 & 25,02 & & & & \\
\cline { 1 - 4 } kontrol & 34 & 1032 & 25,8 & 1,69 & 1,55 & 2,00 & 0,445 \\
\hline
\end{tabular}

Keterangan:

n : jumlah siswa

$\Sigma \mathrm{X}$ : jumlah nilai pretes

$\bar{X} \quad$ : nilai rata-rata pretes

Berdasarkan Tabel 4 dapat dilihat nilai Fhitung $=1,55$ dan nilai $F_{\text {tabel }}$ pada $\alpha=0,05$ dengan $\mathrm{dk}_{(25,34)}$ dari daftar tabel distribusi $\mathrm{F}$ adalah 1,69, maka diperoleh $\mathrm{F}_{\text {hitung }}<\mathrm{F}_{\text {tabel. }}$ Hal ini menunjukkan bahwa kedua kelompok sampel mempunyai varians yang sama (homogen). Untuk mengetahui kesamaan rata-rata dilanjutkan dengan uji t dua pihak 
dengan peluang $1-1 / 2 \alpha$ dan diperoleh thitung 0,445 dan tabel pada $\alpha=0,05$ dengan $\mathrm{dk}=57$ adalah 2,00. Berdasarkan data tersebut dapat disimpulkan thitung terletak diantara $-t_{\text {tabel }}$ dan tabel $(-2,00<0,445<2,00)$, sehingga kedua kelompok sampel memiliki tingkat kemampuan dasar yang setara (homogen).

\section{b. Uji hipotesis}

Berdasarkan hasil uji hipotesis maka diperoleh data seperti tertera pada Tabel 5.

Tabel 5. Hasil Uji Hipotesis

\begin{tabular}{lllcccc}
\hline Kelas & $\mathrm{N}$ & $\sum \mathrm{X}$ & $X$ & Sgab & tabel & $T_{\text {hitung }}$ \\
\hline Eksp & 25 & 2224 & 61,77 & & & \\
\cline { 1 - 4 } kontrol & 34 & 2056 & 54,1 & 9,61 & 3,42 & 1,74 \\
\hline
\end{tabular}

Keterangan:

n : jumlah siswa

$\Sigma \mathrm{X} \quad$ : jumlah selisih nilai pretes dan postes

$\bar{X} \quad$ : nilai rata-rata selisih pretes dan postes

Uji hipotesis dilakukan dengan menggunakan uji satu pihak dengan kriteria probabilitas $(1-\alpha)$ pada taraf signifikan $\alpha=0,05$ dan $d k\left(n_{1}+n_{2}-2\right)=57$. Dari tabel $X$ dapat dilihat bahwa nilai thitung $=3,42$ dan $t_{\text {tabel }}=1,67$. Hal ini berarti thitung $>t_{\text {tabel }}(3,42>$ 1,67), maka hipotesis "penerapan model pembelajaran kooperatif Word Square dapat meningkatkan prestasi belajar siswa pada pembelajaran kimia pokok bahasan Koloid di kelas XI SMKN 2 Pekanbaru” dapat diterima.

Penerapan model pembelajaran kooperatif word square dapat meningkatkan prestasi belajar siswa pada pokok bahasan Koloid di kelas XI SMKN2 Pekanbaru dengan peningkatan sebesar $13,71 \%$. Artinya pengaruh penerapan model pembelajaran kooperatif word square terhadap peningkatan prestasi siswa meningkat sebesar 13,71\%.

Adapun tahap-tahap pembelajaran word square adalah : mula-mula guru menyampaikan materi. Kemudian guru membagikan LKS yaitu lembaran kegiatan word square. Setelah itu siswa disuruh menjawab soal dan mengarsir huruf dalam kotak sesuai jawaban. Akhirnya guru memberikan poin untuk setiap jawaban benar dalam kotak word square. Peningkatan prestasi belajar siswa kelas eksperimen dengan model kooperatif word square terjadi karena model pembelajaran kooperatif word square menuntut siswa terlibat aktif saat proses pembelajaran. Siswa melakukan diskusi dalam kelompok masing-masing untuk menyelesaikan LKS. Pengerjaan LKS bertujuan 
memfasilitasi siswa untuk membangun pengetahuan dasar siswa yang selanjutnya di berikan uji pemahaman dengan permainan word square. Keaktifan siswa dapat dilihat dari aktivitas siswa yang mengajukan pertanyaan, menjawab pertanyaan dan menyampaikan pendapat. Keaktifan siswa menandakan adanya motivasi belajar siswa untuk mengikuti pelajaran. Motivasi siswa terlihat dari kerja sama siswa untuk mendapatkan nilai tinggi dan saling berlomba untuk mendapatkan penghargaan kelompok.

Selain dapat mengaktifkan siswa, Penerapan model pembelajaran kooperatif word square dapat menciptakan suasana belajar yang berbeda. Biasanya proses pembelajaran yang diterima siswa adalah ceramah, tanya jawab dan pemberian tugas. Permainan word square pada proses pembelajaran dapat menciptakan suasana belajar yang menyenangkan, mudah dipahami dan lebih lama diingat.

Pengaruh penerapan model pembelajaran kooperatif word square juga dapat dilihat dari nilai rata-rata hasil belajar kognitif pada setiap pertemuan. Setiap pertemuan diperoleh rata-rata hasil belajar kognitif siswa di kelas eksperimen lebih tinggi dibandingkan kelas kontrol. Nilai rata-rata hasil belajar kognitif kelas eksperimen dan kelas kontrol dapat dilihat pada Gambar 1.

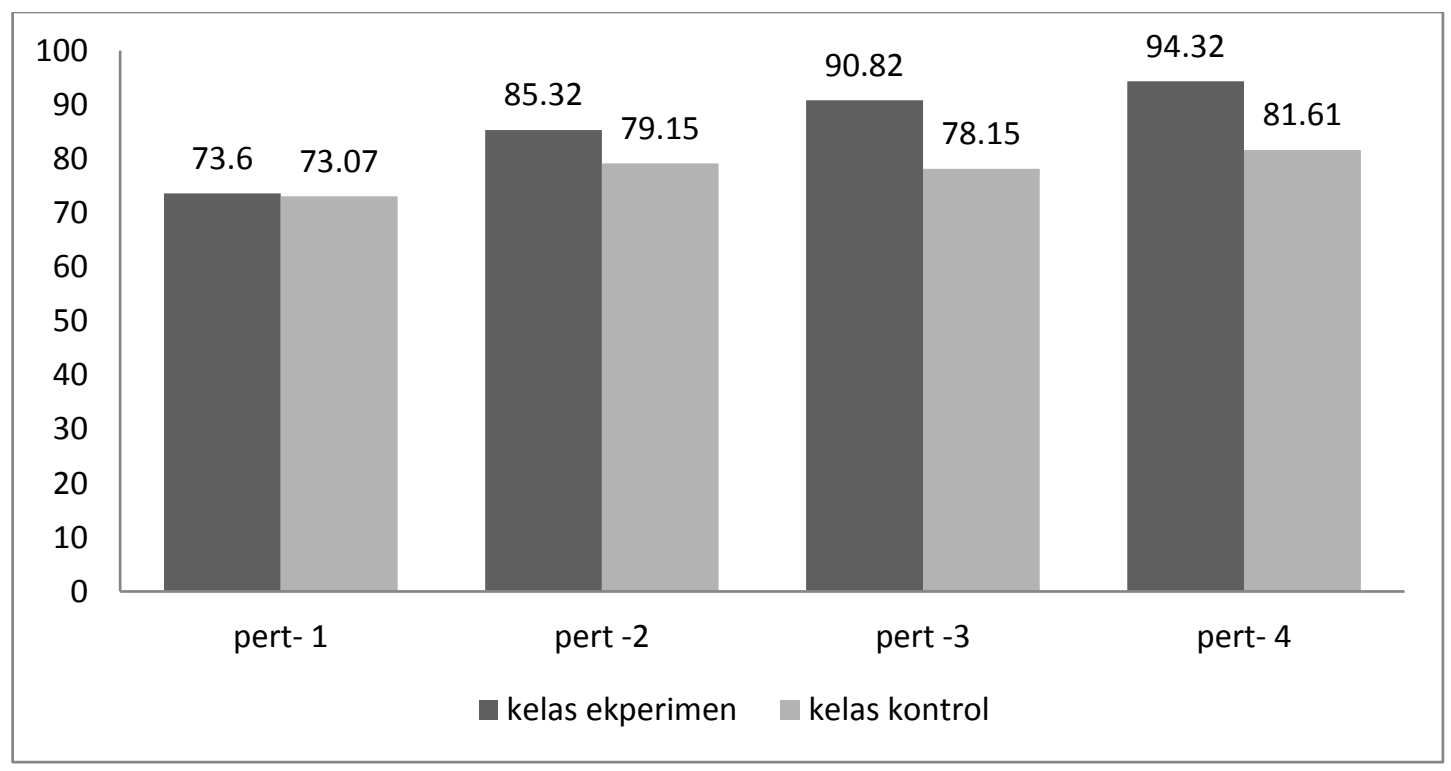

Gambar 1. Diagram nilai rata-rata hasil belajar kognitif pada kelas eksperimen dan kelas control.

Pada pertemuan pertama nilai rata-rata hasil belajar kognitif kelas eksperimen dan kelas kontrol tidak berbeda secara signifikan. Siswa pada kelas eksperimen tidak 
memahami permainan sehingga model pembelajaran kooperatif tidak berlangsung dengan baik. Pada pertemuan selanjutnya nilai rata-rata hasil belajar kognitif kelas eksperimen lebih tinggi daripada nilai rata-rata kelas kontrol.

Guru akan memberikan penghargaan kepada kelompok yang terbaik berdasarkan nilai perkembangan siswa setiap mengikuti pembelajaran. Penghargaan kelompok merupakan suatu ciri dari pembelajaran kooperatif seperti yang dikemukakan oleh Lie (2004). Pembelajaran kooperatif adalah pembelajaran yang menitikberatkan pada gotong royong dan kerja sama kelompok sehingga akan mengaktifkan siswa dalam proses belajar yang dapat meningkatkan prestasi belajar siswa.

Nilai perkembangan masing-masing kelompok pada pertemuan I tergolong super. Hal ini karena perbedaan antara nilai dasar dengan nilai evaluasi I berbeda signifikan sehingga nilai perkembangan semua kelompok tergolong super. Penghargaan kelompok untuk pertemuan I didasarkan pada pemenang permainan word square yaitu kelompok 3. Pada pertemuan II, kelompok yang memiliki nilai perkembangan rata-rata 30 (super) ada 3 kelompok maka Penghargaan kelompok didasarkan pada pemenang permainan word square yaitu kelompok 7. Pada pertemuan III, kelompok yang memiliki nilai tertinggi adalah kelompok 3 dengan nilai perkembangan rata-rata sebesar 25 (Super). Pada pertemuan IV, kelompok yang memiliki nilai perkembangan rata-rata 20 (hebat) ada 3 kelompok maka Penghargaan kelompok didasarkan pada pemenang permainan word square yaitu kelompok 4. Berdasarkan hasil tersebut, dapat dilihat bahwa kelompok 3 dua kali menjadi kelompok dengan nilai perkembangan tertinggi selama proses pembelajaran Koloid.

\section{KESIMPULAN}

Berdasarkan hasil analisis data dan pembahasan maka dapat disimpulkan bahwa :

1. Penerapan model pembelajaran kooperatif word square dapat meningkatkan prestasi belajar siswa pada pokok bahasan Koloid di kelas XI SMK Negeri 2 Pekanbaru.

2. Persentase peningkatan prestasi belajar kimia siswa melalui penerapan model pembelajaran kooperatif word square pada pokok bahasan Koloid di kelas XI SMKN 2 Pekanbaru adalah 13,71\%. 


\section{DAFTAR PUSTAKA}

Hamid, Saleh, 2011, Metode Edutainment, Diva Press, Jakarta

Lie, A. 2007. Cooperative Learning; Mempraktikan Cooperative Learning di ruangruang kelas, Grasindo, Jakarta.

Nazir, Moh, 2003. Metode Penelitian, Ghalia Indonesia, Jakarta.

Santoso , 2011, Model Pembelajaran Word square, http://raseko.blogspot.com/2011/05/model-pembelajaran-word-square.html. ( 03 maret 2012 ).

Subana, Moersetyo Rahadi dan Sudradjat, 2000, Statistik Pendidikan, Pustaka Setia, Bandung.

Suyatno, 2009, Menjelajah Pembelajaran Inovatif, Masmedia Buana Pustaka, Sidoarjo.

Wijana, E,2011, penerapan model belajar word square untuk meningkatkan hasil belajar siswa pada pembelajaran matematika (penelitian tindakan kelas siswa VIIIC SMP Al-Falah Karawangi Depok).

http://skripsiekawijana.blogspot.com/2011/09/penerapan-model-belajar-wordsquare, html(29 februari 2012). 